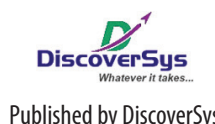

Published by DiscoverSys

\title{
Association between blood glucose level with glycemic load, physical activity and compliance to medication among Diabetes Mellitus (DM) patients in Buleleng District General Hospital, Bali Province
}

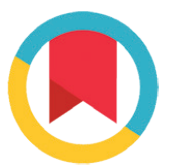

CrossMark

\author{
Ketut Adi Jaya Sutana, ${ }^{1,2 *}$ Komang Ayu Kartika Sari, ${ }^{2,3}$ I Wayan Weta, ${ }^{2,3}$ Ketut Suastika ${ }^{2,4}$
}

\section{ABSTRACT}

Background and purpose: The prevalence of diabetes mellitus (DM) in Indonesia is increasing, including in Buleleng District, Bali Province. Studies regarding determinants of blood glucose control in DM patients show varied findings. This study aims to examine association between blood glucose level with physical activity, compliance to medication and glycemic load among DM patients.

Methods: A cross-sectional survey was conducted in Buleleng District General Hospital from March to April 2017. A total of 73 patients were concecutively recruited to participate in our study. Data were collected through interview, observation and measurement. Data collected included socio-demographic characteristics, fasting blood glucose level, 1-hour and 2-hour postprandial blood glucose levels, carbohydrate intake, body mass index, glycemic index, glycemic load, physical activity, genetic or family history, and compliance to medication. A bivariate analysis was performed to examine association between independent variables and blood glucose levels. Multivariate analysis was also conducted to calculate adjusted odd ratio using a binary logistic regression.
Results: Our study found that blood glucose levels of most respondents were relatively well managed-63\% for fasting, $61.6 \%$ for 1-hour postprandial, and 63\% for 2-hours postprandial. Multivariate analysis revealed that fasting blood glucose level were associated with regular physical activities (AOR=74.09; 95\%Cl: 7.52-729.69) and compliance to medication ( $A O R=11.90 ; 95 \% \mathrm{Cl}$ : 2.24-63.29). Furthermore, 1-hour postprandial blood glucose level were associated with breakfast glycemic load (AOR=0.63; 95\%Cl: 0.47-0.85) and compliance to medication ( $A O R=27.29 ; 95 \% \mathrm{Cl}$ : 2.29-323.95), while 2-hour postprandial blood glucose level were associated with breakfast glycemic load (AOR $=0.69 ; 95 \% \mathrm{Cl}$ : $0.54-$ 0.89 ) and compliance to medication ( $\mathrm{AOR}=19.81 ; 95 \% \mathrm{Cl}$ : 2.31 170.14).

Conclusions: Factors associated with fasting blood glucose level were regular physical activities and adherence to medication, while 1-hour and 2-hours postprandial blood glucose levels were both influenced by breakfast glycemic load and compliance to medication.

Keywords: glycemic load, physical activity, compliance to medication, diabetes mellitus

Cite This Article: Sutana, K.A.J., Sari, K.A.K., Weta, I.W., Suastika, K. 2017. Association between blood glucose level with glycemic load, physical activity and compliance to medication among Diabetes Mellitus (DM) patients in Buleleng District General Hospital, Bali Province. Public Health and Preventive Medicine Archive 5(2): 117-123. D01:10.15562/phpma.v5i2.25

'Buleleng District General Hospital, ${ }^{2}$ Public Health Postgraduate Program Udayana University, ${ }^{3}$ Department of Community and Preventive Medicine Faculty of Medicine Udayana University, ${ }^{4}$ Internal Medicine Department Faculty of Medicine Udayana University/Sanglah General Hospital Denpasar
${ }^{*}$ Correspondence to:

Ketut Adi Jaya Sutana, Buleleng District General Hospital irenedy61@yahoo.co.id

\section{INTRODUCTION}

The prevalence of diabetes mellitus (DM) is increasing at both regional and global levels. ${ }^{1}$ International Diabetes Federation reported that as many as 415 million adult population in 2015 lived with DM and it was predicted to reach 642 million patients in 2040. ${ }^{2}$ The total DM patients in Indonesia was increased from 9.1 million people in $2014^{3}$ to 10 million patients in $2015,{ }^{2}$ and it was predicted to reach 21.3 million patients by $2030 .{ }^{4}$ In Buleleng District, a survey revealed that the proportion of reported family members who have been diagnosed with DM by health providers was increased from $0.9 \%$ in $2007^{5}$ to $1.7 \%$ in $2013 .^{6}$ The total number of DM out-patients in District General Hospital of Buleleng was 11,260 in 2016, ${ }^{7}$ whereas in mid-2017 (up to May), the total DM out-patients has reached $4,728 .^{8}$

A high level of blood sugar leads to several complications between five to ten years after the diagnosis, which include: blindness, kidney failure, gangrene, and other cardiovascular diseases. ${ }^{9}$ The management of DM is essential because DM is a lifetime disease. Prevention measures to delay such complications are critical for patients, for example blood sugar control using fasting and post-prandial blood glucose levels as indicators. ${ }^{10}$

Several studies in hospital settings in Indonesia have documented that blood sugar control practices among DM patients were poor. A study at Internal Medicine Polyclinic at Dr. Kariadi Hospital, Semarang City in 2008 found that as many as $76.1 \%$ of DM patients presented with a high fasting blood glucose level and 78.3\% DM patients presented with a high 2-hour postprandial blood glucose level. ${ }^{11}$ A study in Sanglah General Hospital Denpasar in 2012 reported that a poorly managed blood glucose level was found among $65.1 \%$ of DM in-patients. ${ }^{12}$ 
In addition, a study at Diabetes Polyclinic at $\mathrm{Dr}$ Soetomo Hospital revealed that as many as $66 \%$ of DM patients were found to have poorly managed blood sugar levels. ${ }^{13}$

Studies investigating factors associated with blood sugar management show varies results. A study at Tugorejo District Hospital, Semarang conducted in 2014 found that a physical exercise program can improve blood sugar level of type 2 DM patients. ${ }^{14}$ Another study conducted at Arja Winangun District Hospital Cirebon in 2012 revealed that physical activities, regular exercise, and diet compositions are associated with management of blood sugar level among DM patients. ${ }^{15}$ A study in Dr. Kariadi Hospital, Semarang City in 2014 also found that total carbohydrate intake and glycemic index can influence fasting and 2-hours postprandial blood glucose levels. ${ }^{11}$ Studies conducted at public health centres also show similar findings. A study at Kembiritan Public Health Centre in Banyuwangi District in 2014 reported that compliance to medication and nutritional status might improve glycemic control among type 2 DM patients. ${ }^{16}$ In addition, a study conducted at all public health centres in South Denpasar Subdistrict in 2013 revealed that obesity based on waist circumference is a risk factor for developing type $2 \mathrm{DM}^{17}$

This study aims to examine association between blood sugar level among type-2 DM out-patients with physical activity, compliance to medication and glycemic load.

\section{METHODS}

A cross-sectional survey was conducted from March to April 2017 in Buleleng District Hospital. A total of 73 patients were selected using a concecutive technique from all DM patients visiting out-patient polyclinic services at Internal Medicine Polyclinic Buleleng District Hospital. Data on carbohydrate intake, glycemic index, and glycemic load were collected using a semi quantity-food frequency questionnaire (SQ-FFQ) and a direct observation using a food record form..$^{18}$ Data on fasting and 2-hours postprandial blood glucose levels were obtained from laboratory result, while the 1-hour postprandial blood glucose level were obtained using a glucometer. Data on physical activity, family history or genetic and compliance to medication were obtained from a structured interview. Specific to compliance data, we used the Morisky Medication Adherence Scale (MMAS-8). ${ }^{19,20}$ Data on body mass index (BMI) were calculated from body weight and height variables. All data collection processes namely interview, observation, and measurement were conducted by the researcher and two trained enumerators. Informed consent was obtained from all respondents prior to data collection. Bivariate analysis was conducted to test the mean difference and correlation between two variables. Mean difference was tested using Mann Whitney $U$ test while correlation was tested using Kendal Tau_b. Multivariate analysis was conducted using a binary logistic regression to obtain Adjusted Odds Ratio (AOR) at 95\% confidence interval level. Our study protocol has been approved by the Human Research Ethics Committees Faculty of Medicine Udayana University and Sanglah General Hospital Denpasar.

\section{RESULTS}

Table 1 depicts characteristics of respondent by age, sex, carbohydrate intake, glycemic index, glycemic load and blood sugar levels. The majority of respondents aged between 40 to 49 years $(52.1 \%)$ with an average of $47.34 \pm 7.02$ years and female (57.5\%). Over the last month, most of respondents consumed adequate amount of carbohydrate $(72.6 \%)$, with high glycemic index $(60.3 \%)$, and with low glycemic load (65.8\%). During breakfast at the hospital, the majority of respondents consumed adequate amount of carbohydrate (64.4\%) with low glycemic index (52.1\%). The proportion of glycemic load was divided into three categories: low (30.1\%), moderate (37.0\%), and high (32.9\%). Blood glucose levels of most respondents were relatively well managed $-63 \%$ for fasting, $61.6 \%$ for 1 -hour postprandial, and $63 \%$ for 2-hours postprandial blood glucose levels.

Table 2 describes our bivariate analysis using the Mann Whitney U test. Our analysis revealed that fasting blood glucose level were associated with physical activities and compliance to medication ( $<<0.001$ ), while 1 -hour and 2-hours postprandial blood glucose levels were associated with compliance to medication $(\mathrm{p}<0.001)$.

Table 3 shows our bivariate analysis using the Kendall Tau_b correlation test to examine association between dependent and independent variables. Our analysis showed that fasting blood glucose level was significantly correlated with carbohydrate consumption in the last month ( $r=0.197 ; \mathrm{p}=0.015)$, glycemic index in the last month $(\mathrm{r}=0.501$; $\mathrm{p}<0.001$ ), and glycemic load in the last month $(r=0.529 ; p<0.001)$. Furthermore, 1-hour postprandial blood glucose level was associated with carbohydrate intake in the morning or during breakfast $(r=0.315 ; \mathrm{p}<0.001)$, breakfast glycemic index $(\mathrm{r}=0.556 ; \mathrm{p}<0.001)$, and breakfast glycemic load $(r=0.608 ; p<0.001)$, while the 2 -hour postprandial blood glucose level was correlated with carbohydrate intake during breakfast $(\mathrm{r}=0.325 ; \mathrm{p}<0.001)$, 
Table 1 Distribution of respondents by age, sex, carbohydrate intake, glycemic index, glycemic load and blood glucose level

\begin{tabular}{|c|c|c|}
\hline Variables & $n=73$ & $\%$ \\
\hline \multicolumn{3}{|l|}{ Characteristics } \\
\hline \multicolumn{3}{|l|}{ Age (years) } \\
\hline$\leq 39$ & 13 & 17.8 \\
\hline $40-49$ & 38 & 52.1 \\
\hline $50-59$ & 20 & 27.4 \\
\hline$\geq 60$ & 2 & 2.7 \\
\hline \multicolumn{3}{|l|}{ Sex } \\
\hline Male & 31 & 42.5 \\
\hline Female & 42 & 57.5 \\
\hline \multicolumn{3}{|c|}{ Diet patterns over the last month } \\
\hline \multicolumn{3}{|l|}{ Carbohydrate intake } \\
\hline High & 20 & 27.4 \\
\hline Adequate & 53 & 72.6 \\
\hline \multicolumn{3}{|l|}{ Glycemic index } \\
\hline Low & 16 & 21.9 \\
\hline Moderate & 13 & 17.8 \\
\hline High & 44 & 60.3 \\
\hline \multicolumn{3}{|l|}{ Glycemic load } \\
\hline Low & 48 & 65.8 \\
\hline Moderate & 8 & 11.0 \\
\hline High & 17 & 23.2 \\
\hline \multicolumn{3}{|l|}{ Breakfast } \\
\hline \multicolumn{3}{|l|}{ Carbohydrate intake } \\
\hline High & 26 & 35.6 \\
\hline Adequate & 47 & 64.4 \\
\hline \multicolumn{3}{|l|}{ Glycemic index } \\
\hline Low & 38 & 52.1 \\
\hline Moderate & 16 & 21.9 \\
\hline High & 19 & 26.0 \\
\hline \multicolumn{3}{|l|}{ Glycemic load } \\
\hline Low & 22 & 30.1 \\
\hline Moderate & 27 & 37.0 \\
\hline High & 24 & 32.9 \\
\hline \multicolumn{3}{|l|}{ Blood sugar levels } \\
\hline \multicolumn{3}{|l|}{ Fasting } \\
\hline Poorly controlled & 27 & 37.0 \\
\hline Well managed & 46 & 63.0 \\
\hline \multicolumn{3}{|l|}{ 1-hour postprandial } \\
\hline Poorly controlled & 28 & 38.4 \\
\hline Well managed & 45 & 61.6 \\
\hline \multicolumn{3}{|l|}{ 2-hours postprandial } \\
\hline Poorly controlled & 27 & 37.0 \\
\hline Well managed & 46 & 63.0 \\
\hline
\end{tabular}

breakfast glycemic index $(\mathrm{r}=0.580 ; \mathrm{p}<0.001)$, and breakfast glycemic load $(r=0.617 ; \mathrm{p}<0.001)$.

Table 4 presents our multivariate analysis which found that fasting blood sugar level were significantly associated with regular physical activities (AOR=74.09; 95\%CI: 7.522-729.69) and compliance to medication (AOR=11.9; 95\%CI: 2.24163.29). Furthermore, our analysis also revealed that 1-hour postprandial blood glucose level were significantly associated with compliance to medication $\quad(\mathrm{AOR}=27.29 ; 95 \% \mathrm{CI}: 2.298-323.95)$ and breakfast glycemic load (AOR $=0.63$; $95 \% \mathrm{CI}$ : $0.470-0.848$ ), while the 2-hours postprandial blood glucose level were associated with compliance to medication (AOR=19.81; 95\%CI: 2.306-170.14) and breakfast glycemic load (AOR $=0.69 ; 95 \% \mathrm{CI}$ : 0.543-0.888). Other variables which included genetic or family history, carbohydrate intake and glycemic index were not associated with the control of blood glucose level.

\section{DISCUSSION}

Our study found that regular physical activities was significantly associated with control of fasting blood sugar, but were not associated with 1-hour and 2-hours postprandial blood glucose levels. It can be explained that blood glucose was transformed into energies through oxidation processes during physical activities. ${ }^{21}$ In addition, physical activities also lead to an increased blood flow resulting in opening up of more capillary bands as well as improving effectiveness of insulin receptors. ${ }^{21}$ Our study revealed that regular physical activities were not associated with 1-hour and 2-hours post prandial blood glucose levels because the effects of diet patterns as well as the compliance factor towards medication are more dominant on the multivariate analysis. A high glycemic load might reduce the control of 1-hour and 2-hours postprandial blood glucose, while compliance to medication may improve the control of 1-hour and 2-hours postprandial blood glucose.

Carbohydrate intake was not associated with fasting and 2-hours postprandial blood glucose levels, however it significantly influenced the 1-hour post prandial blood glucose level though the 95\% confidence interval was close to 1 indicating that it might be clinically insignificant. Other study conducted at Internal Medicine Polyclinic of Prof. Dr. Soerojo Hospital found that carbohydrate intake was not associated with blood sugar levels among DM patients $(\mathrm{p}=0.717){ }^{22}$ In addition, a study at Dr. Moewardi District Hospital of Surakarta found that carbohydrate intake was not correlated with fasting and 2-hours postprandial blood glucose levels among DM patients $(\mathrm{p}=0.346){ }^{23}$ 
Table 2 The difference between blood sugar levels by physical activity, genetic or family history and compliance to medication

\begin{tabular}{|c|c|c|c|c|}
\hline \multirow[b]{2}{*}{ Variables } & \multirow[b]{2}{*}{ n (\%) } & \multicolumn{3}{|c|}{ Median of blood sugar levels (K1-K3)* } \\
\hline & & Fasting & 1-hour postprandial & 2-hours postprandia \\
\hline \multicolumn{5}{|c|}{ Physical activity } \\
\hline Regular & $33(45.2)$ & $107(101-114)$ & $173(164-179)$ & $154(148-167)$ \\
\hline \multirow[t]{2}{*}{ Not regular } & $40(54.8)$ & $144(117-154)$ & $186(168-228)$ & $170(149-211)$ \\
\hline & & $\mathrm{p}<0.001$ & $\mathrm{p}=0.088$ & $\mathrm{p}=0.080$ \\
\hline \multicolumn{5}{|c|}{ Genetic or family history } \\
\hline Yes & $30(41.1)$ & $126(110-150)$ & $191(161-235)$ & $176(145-215)$ \\
\hline \multirow[t]{2}{*}{ No } & $43(58.9)$ & $115(105-135)$ & $174(167-211)$ & $154(148-193)$ \\
\hline & & $\mathrm{p}=0.176$ & $\mathrm{p}=0.180$ & $\mathrm{p}=0.223$ \\
\hline \multicolumn{5}{|c|}{ Compliance to medication } \\
\hline High & $52(71.2)$ & $110(104-122)$ & $172(161-179)$ & $154(145-167)$ \\
\hline \multirow[t]{2}{*}{ Low } & $21(28.8)$ & $148(128-154)$ & $222(203-256)$ & $206(187-238)$ \\
\hline & & $\mathrm{p}<0.001$ & $\mathrm{p}<0.001$ & $\mathrm{p}<0.001$ \\
\hline
\end{tabular}

${ }^{\star}$ Tested using Mann Whitney U

Table 3 Correlation between blood sugar levels with BMI, carbohydrate intake, glycemic index and glycemic load

\begin{tabular}{|c|c|c|c|}
\hline Variables & Blood sugar levels & $\mathbf{r}$ & p value \\
\hline \multirow[t]{3}{*}{ Body mass index (BMI) } & Fasting & 0.085 & 0.296 \\
\hline & 1-hour postprandial & 0.083 & 0.305 \\
\hline & 2-hours postprandial & 0.084 & 0.303 \\
\hline \multicolumn{4}{|l|}{ Carbohydrate intake } \\
\hline Over the last month & Fasting & 0.197 & 0.015 \\
\hline Breakfast & 1-hour postprandial & 0.315 & $<0.001$ \\
\hline Breakfast & 2-hours postprandial & 0.325 & $<0.001$ \\
\hline \multicolumn{4}{|l|}{ Glycemic index } \\
\hline Over the last month & Fasting & 0.501 & $<0.001$ \\
\hline Breakfast & 1-hour postprandial & 0.556 & $<0.001$ \\
\hline Breakfast & 2-hours postprandial & 0.580 & $<0.001$ \\
\hline \multicolumn{4}{|l|}{ Glycemic load } \\
\hline Over the last month & Fasting & 0.529 & $<0.001$ \\
\hline Breakfast & 1-hour postprandial & 0.608 & $<0.001$ \\
\hline Breakfast & 2-hours postprandial & 0.617 & $<0.001$ \\
\hline
\end{tabular}

Our study revealed that glycemic load was not associated with the control of fasting blood glucose but was correlated with the control of 1 -hour and 2-hours postprandial blood glucose levels. It might be due to the dominant effects of physical activities and compliance to medication on fasting blood sugar level. Our descriptive analysis suggested that there was a significant difference of fasting blood glucose level based on physical activities and compliance to medication. Median value of fasting blood glucose level among patients who perform regular physical activities was significantly lower than those who do not regularly exercise. Similarly, median value of fasting blood sugar level among patients with high compliance was lower than those with poor compliance. In addition, during the fasting period there was no glucose consumption for about 10-12 hours where all blood glucose came from glycogenolysis on the liver. ${ }^{21}$ Our finding is consistent with other study conducted at Batua Raya Public Health Centre and Bara Barayya Public Health Centre in Makasar City which found that there was a significant association between blood glucose level and glycemic load $(\mathrm{p}=0.004){ }^{24}$ Other study at Dr. Kariadi Hospital in Semarang City also found that there was a positive association between 
Table 4 Multivariate analysis using a binary logistic regression between blood sugar levels and several independent variables

\begin{tabular}{|c|c|c|c|c|c|}
\hline Independent variables ${ }^{1}$ & Blood sugar levels ${ }^{2}$ & B & Sig. & $\operatorname{Exp}(B)$ & $95 \% \mathrm{Cl}$ \\
\hline Physical activity ${ }^{3}$ & Fasting & 4.305 & $<0.001$ & 74.09 & $7.522-729.69$ \\
\hline Compliance to medication ${ }^{4}$ & & 2.477 & 0.004 & 11.9 & $2.241-63.290$ \\
\hline Constant value & & -2.408 & 0.002 & & \\
\hline Breakfast glycemic index ${ }^{5}$ & 1-hour postprandial & -0.460 & 0.002 & 0.631 & $0.470-0.848$ \\
\hline Compliance to medication ${ }^{4}$ & & 3.306 & 0.009 & 27.29 & $2.298-323.95$ \\
\hline Physical activity ${ }^{3}$ & & 1.905 & 0.097 & 6.719 & $0.707-63.865$ \\
\hline Carbohydrate intake during the breakfast ${ }^{5}$ & & -0.072 & 0.046 & 0.931 & $0.867-0.999$ \\
\hline Constant value & & 10.615 & 0.003 & & \\
\hline Breakfast glycemic load ${ }^{5}$ & 2-hours postprandial & -0.364 & 0.004 & 0.695 & $0.543-0.888$ \\
\hline Compliance to medication ${ }^{4}$ & & 2.986 & 0.006 & 19.81 & $2.306-170.14$ \\
\hline Carbohydrate intake during the breakfast ${ }^{5}$ & & -0.064 & 0.061 & 0.938 & $0.878-1.003$ \\
\hline Constant value & & 9.396 & 0.003 & & \\
\hline
\end{tabular}

${ }^{1}$ Variables that were included in the multivariate analysis: physical activity, genetic or family history, compliance to medication, carbohydrate intake, glycemic index, and glycemic load

${ }^{2} \mathrm{~A}$ well managed category of fasting, 1-hour postprandial, and 2-hours postprandial glood glucose levels was used as a reference

${ }^{3} \mathrm{~A}$ regular physical exercise was used as a reference

${ }^{4} \mathrm{~A}$ high compliance to medication was used as a reference

${ }^{5}$ The glycemic load and carbohydrate intake during the breakfast were analysed as an interval variable

glycemic load and 2-hour postprandial blood glucose level $(\mathrm{r}=0.775 ; \mathrm{p}<0.001){ }^{11}$

Our study identified that compliance to medication was significantly associated with fasting, 1-hour, and 2-hours postprandial blood glucose levels. In addition, our analysis also revealed that there was a significant difference in median blood glucose values based on compliance to medication. Patients with high compliance were found to have a lower median blood sugar (fasting, 1-hour and 2-hour post prandial) values than those with poor compliance. Our finding is consistent with other study conducted in Umbulharjo II Public Health Centre, Yogyakarta which found that there was a significant association between compliance to medication and blood sugar level among DM patients $\left(\mathrm{OR}=8.57\right.$; 95\% CI: 2.05-35.92) ${ }^{25}$

Our study found that genetic factor or family history was not associated with fasting, 1-hour, and 2-hours post prandial blood glucose levels. This might be due to the dominant effects of the glycemic load and compliance to medication. Our descriptive analysis suggested that most of our patients consumed a low glycemic load diet $76.7 \%$ in the last month, $72.6 \%$ during the breakfast at the hospital) and adhered to their medication either oral tablet or insulin injection (71.2\%). These findings are consistent with a cross-sectional survey among BMPK employees and Local Secretariat of Depok City in 2014 which found that history of DM in the family was not associated with fasting blood glucose level $(\mathrm{p}=0.211){ }^{26}$ However, a cross-sectional study conducted at Cengkareng Public Health Centre in
West Jakarta found that family history or genetic increased the likelihood to acquire $\mathrm{DM}(\mathrm{OR}=4.19$; 95\%CI: 1.25-14.08). ${ }^{27}$ In our study, all respondent are DM patients therefore family history was no longer a dominant determinant that influences blood sugar levels.

Our study also found that BMI was not associated with fasting, 1-hour, and 2-hours post prandial blood glucose levels. Our finding is consistent with a cross-sectional study conducted in Nigeria which found that there was no significant association between BMI and random blood glucose level $(\mathrm{r}=0.00 ; \mathrm{p}=0.30) .{ }^{28}$ However, our study is different from cross-sectional studies conducted in India and Estonia which discovered that there was a significant correlation between BMI and blood glucose level among DM patients. ${ }^{29,30}$

Furthermore, our study showed that glycemic index was not correlated with fasting, 1-hour, and 2-hour post prandial blood glucose levels. This might be due to the dominant effects of other independent variables in the multivariate model which included physical activities, compliance to medication, and glycemic load. Our finding is consistent with a nested cohort study conducted in Europe Region which found that food with high glycemic index were not associated with increased risk of acquiring DM. ${ }^{31}$ Another study at Sanglah General Hospital Denpasar also revealed that there was no significant association between glycemic index and the control of blood glucose among DM patients. ${ }^{12}$

One of main limitation of our study is that we utilize glycemic index data from other countries 
due to limited data available on glycemic index for Indonesian food. In addition, our study also uses data on diet patterns over the last month by using SQ-FFQ which very much depends on the memory and recall ability of the respondents.

Our study indicates that there is a growing need for education program for DM patients related to management of blood glucose level covering issues on consumption of low glycemic index food, regular physical activities, and promoting adherence towards medication.

\section{CONCLUSION}

Breakfast glycemic load was associated with an increased of 1-hour and 2-hours postprandial blood glucose levels, however it did not affect the fasting blood glucose level. Regular physical activities were associated with the fasting blood glucose level. The compliance to medication was associated with 1-hour and 2-hours postprandial as well as fasting blood glucose levels.

\section{ACKNOWLEDGEMENT}

We would like to thank Buleleng District Hospital, enumerators, and all respondents who had participated in this study.

\section{REFERENCES}

1. World Health Organization. Global report on diabetes. Geneva: World Health Organization; 2016.

2. International Diabetes Federation. IDF Diabetes atlas seventh edition. Brussels: International Diabetes Federation; 2015.

3. International Diabetes Federation. IDF diabetes atlas sixth edition, 2014 Update. Brussels: International Diabetes Federation; 2014.

4. Sarah W, Roglic G, Green A, Sicree R, King H. Global prevalence of diabetes: estimates for the year 2000 and projection for 2030. Diabetes Care. 2004; 27(5): 1051.

5. Ministry of Health of Indonesia. Riset Kesehatan Dasar (Riskesdas) Provinsi Bali tahun 2007 [Basic Health Survey for Bali Province 2007]. Jakarta: Ministry of Health of Indonesia; 2009.

6. Ministry of Health of Indonesia. Riset kesehatan dasar dalam angka Provinsi Bali tahun 2013 [Basic health survey in number for Bali Province 2013]. Jakarta: Ministry of Health of Indonesia; 2013

7. Buleleng District General Hospital. Laporan tahunan RSUD Kabupaten Buleleng tahun 2016 [Annual report of Buleleng District Hospital 2016]. Buleleng: Buleleng District General Hospital; 2017.

8. Program Planning and Information Department. Bank data: 10 besar penyakit rawat jalan dan rawat inap [Bank data: top 10 diseases for in-patient and out-patient services] [cited 2017 Jul 28]. Available from: https://rsud. bulelengkab.go.id/bankdata

9. Smeltzer SC, Bare BG, Hinkle JL, Cheever K. Handbook for brunner \& suddarth's textbook of medical surgical nursing. twelfth ed. Philadelphia: Lippincott Williams \& Wilkins. 2010: 255-275.
10. American Diabetes Association. Standards of medical care in diabetes-2016. Journal of Clinical Appleid and Research Education. 2016; 39: S23-S35.

11. Fitri R, Wirawanni Y. Hubungan Konsumsi karbohidrat, konsumsi total energi, konsumsi serat, beban glikemik dan latihan jasmani dengan kadar glukosa darah pasien diabetes mellitus tipe 2 [Association between carbohydrate consumption, total energy consumption, glycemic load, physical activity and blood glucose level among type $2 \mathrm{DM}$ patients]. Jurnal of Nutrition Health. 2014; 2(3): 15-6.

12. Wiardani Ni K, Sariasih NN, Swandari Y. Indeks glikemik menu makanan rumah sakit dan pengendalian glukosa darah pada pasien diabetes melitus rawat inap di RSUP Sanglah Denpasar [Glicemic index of the hospital menu and the control of blood glucose level among DM in-patients at Sanglah General Hospital Denpasar]. Jurnal Skala Husada. 2012; 9: 44-50.

13. Fahmiyah I, Latra Nyoman I. Faktor yang mempengaruhi kadar gula darah diabetes di RSUD Dr. Soetomo Surabaya menggunakan regresi probit biner [Factors associated to blood glucose level among DM patients at Dr. Soetomo District Hospital, Surabaya City using the probit binary regression]. Jurnal Sains dan Seni ITS. 2016; 5(2): 456-461.

14. Wulandari P. Analisis faktor penyebab kadar gula darah pada penderita diabetes mellitus (DM) tipe-2 di RSUD Tugurejo Semarang [Determinants of blood glucose level among type-2 DM patients at Tugurejo District Hospital, Semarang City]. Jurnal Kesehatan VisiKes. 2015; 14(1): 52-53.

15. Anani S, Udiyono A, Ginanjar P. Hubungan antara perilaku pengendalian diabetes dan kadar glukosa darah pasien rawat jalan diabetes melitus (studi kasus di RSUD Arjawinangun Kabupaten Cirebon) [Association between blood glucose management practices and blood glucose level among DM out-patients - a case study at Arjawinangun District Hospital of Cirebon City]. Jurnal Kesehatan Masyarakat. 2012; 1(2): 466-478.

16. Purwitaningtyas RY, Putra IW. AE, Wirawan DN. Faktor risiko kendali glikemik buruk pada penderita diabetes melitus tipe 2 di Puskesmas Kembiritan Kabupaten Banyuwangi [Risk factors of poor glycemic control among type-2 DM patients at Kembiritan Community Health Centre, Banyuwangi District]. Public Health and Preventive Medicine Archive. 2015; 3(1): 81-87.

17. Trisnawati S, Widarsa T, Suastika K. Faktor risiko diabetes mellitus tipe 2 pasien rawat jalan di Puskesmas Wilayah Kecamatan Denpasar Selatan [Risk factors of type-2 DM among patients who accessed out-patient services at community health centres in South Denpasar Subdistrict]. Public Health and Preventive Medicine Archive. 2013; 1(1): $1-6$.

18. Arasj F. Ilmu Gizi : teori \& aplikasinya [Nutrition science: theory and its application]. Jakarta: EGC; 2016.

19. Morisky DE, Ang A, Krousel-Wood M, et al. Predictive validity of a madication adherence measure in an outpatient setting. The Journal of Clinical Hypertension. 2008; 10: 348-354.

20. M Al-Haj Mohd MM, Phung H, Sun J, et al. Improving adherence to medication in adults with diabetes in the United Arab Emirates. BMC Public Health. 2016; 16: 1-10.

21. Marks DB, Marks AD, Smith CM. Translated by Brahm U. Pendit. Biokimia kedokteran dasar: sebuah pendekatan klinis [Biochemestry for basic medicine: a clinical approach]. Jakarta: EGC; 2000.

22. Astuti CM, Setiarini A. Faktor-faktor yang berhubungan dengan pengendalian kadar glukosa darah pasien diabetes melitus tipe 2 rawat jalan di poliklinik penyakit dalam RSJ Prof . Dr . Soerojo Magelang Tahun 2013 [Factors associated with the control of blood sugar level among type-2 DM patients at internal medicine polyclinic of Prof. Dr. Soerojo Hospital, Magelang City, 2013] [thesis]. Jakarta: University of Indonesia; 2013. 
23. Witasari U, Rahmawaty S, Zulaekah S. Hubungan tingkat pengetahuan, asupan karbohidrat dan serat dengan pengendalian kadar glukosa darah pada penderita diabetes mellitus tipe 2 [Association between level of knowledge, carbohydrate consumption, fibre intake, and blood glucose level among type-2 DM patients]. Jurnal Penelitian Sains \& Teknologi. 2009; 10(2): 130-138.

24. Idris AM, Jafar N, Indriasari R. Pola makan dengan kadar gula darah pasien DM tipe 2 [Diet Patterns and Blood Glucose Level among Type 2 DM patients]. Jurnal Media Kesehatan Masyarakat Indonesia. 2014; 10: 211-218.

25. Salistyaningsih W, Puspitawati T, Nugroho DK. Hubungan tingkat kepatuhan minum obat hipoglikemik oral dengan kadar glukosa darah pada pasien diabetes melitus tipe 2 [Association between compliance to oral hypoglycemic drugs medication and blood glucose level among type-2 DM patients]. Berita Kedokteran Masyarakat. 2011; 27(4): 215-216.

26. Werdani AR, Triyanti. Asupan karbohidrat sebagai faktor dominan yang berhubungan dengan kadar gula darah puasa [Carbohydrate intake as the dominant risk factor of the fasting blood sugar level]. Jurnal Kesehatan Masyarakat Nasional. 2014; 9(1): 74-75.

27. Trisnawati SK, Setyorogo S. Faktor risiko kejadian diabetes melitus tipe II di Puskesmas Kecamatan Cengkareng Jakarta Barat Tahun 2012 [Risk factors of type-2 DM at Cengkareng Subdistrict Community Health Centre, West Jakarta, 2012]. Jurnal Ilmiah Kesehatan. 2013; 5(1): 7-9.
28. Etukumana EA, Puepet FH, Obadofin MO. Relationship between random blood glucose levels and body mass. Ibom Medical Journal. 2013; 6(1): 37-38.

29. Vittal BG, Praveen G, Deepak P. A Study Of Body mass index in healthy individuals and its relationship with fasting blood sugar. Jurnal of Clinical Diagnostic Research. 2010; 4: 3421-3422.

30. Sepp E, Kolk H, Loivukene K, Mikelsaar M. Higher blood glucose level associated with body mass index and gut microbiota in elderly people. Microbial Ecology in Health \& Disease. 2014; 25: 1-8.

31. Sluijs I, Beulens JWJ, Schouw YT Van Der, A DL Van Der, Buckland G, Kuijsten A, et al. Dietary glycemic index , glycemic load, and digestible carbohydrate intake are not associated with risk of type 2 diabetes in eight European countries. The Journal of Nutrition. 2013; 143(1): 97-99.

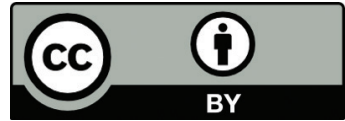

This work is licensed under a Creative Commons Attribution 